\title{
Nutraceuticals Known To Promote Hair Growth Do Not Interfere With The Inhibitory Action of Tamoxifen In MCF7, T47D And BT483 Breast Cancer Cell Lines
}

\section{Richard Baker}

University of Bradford

Giorgio Dell'Acqua

Nutraceutical Wellness, Inc. New York

Aleksander Richards

Nutraceutical Wellness, Inc. New York

M Julie Thornton ( $\sim$ m.j.thornton@bradford.ac.uk)

University of Bradford

\section{Research Article}

Keywords: ERa, ERß, Kelp, Astaxanthin, Saw Palmetto, Tocotrienols, Resveratrol, Curcumin, Ashwagandha

Posted Date: February 3rd, 2022

DOI: https://doi.org/10.21203/rs.3.rs-1167112/v2

License: (c) (i) This work is licensed under a Creative Commons Attribution 4.0 International License.

Read Full License 


\title{
Nutraceuticals known to promote hair growth
}

\author{
do not interfere with the inhibitory action of
}

\section{tamoxifen in MCF7, T47D and BT483 breast}

\section{cancer cell lines}

R Baker', G Dell'Acqua², A Richards ${ }^{2}$ and 'MJ Thornton'1

${ }^{1}$ Centre for Skin Sciences, Faculty of Life sciences, University of

Bradford, Bradford, UK; ${ }^{2}$ Nutraceutical Wellness, Inc. New York, USA

${ }^{*}$ Corresponding author Prof MJ Thornton: m.j.thornton@bradford.ac.uk

Keywords:

ER $\alpha$, ER $\beta$, Kelp, Astaxanthin, Saw Palmetto, Tocotrienols, Resveratrol, Curcumin, Ashwagandha

\section{Abbreviations:}

$\mathrm{ER}=$ estrogen receptor, $\mathrm{SERM}=$ selective estrogen receptor modulator, $\mathrm{TAM}=$ tamoxifen, E2 $=17 \beta$-estradiol, $K=K e l p$, Ast=Astaxanthin, $\mathrm{SP}=$ Saw Palmetto, $\mathrm{T}=$ Tocotrienols, $\mathrm{M}=$ Maca, $\mathrm{H}=$ Horsetail, $\mathrm{R}=$ Resveratrol, $\mathrm{C}=$ Curcumin, $\mathrm{Ash}=$ Ashwagandha, $\mathrm{AC}=$ Alternative Curcumin, $\mathrm{MRR}=$ mitochondrial retrograde response, $\mathrm{NAM}=$ nucleus associated mitochondria, ERB$041=\mathrm{ER} \beta$ agonist, $\mathrm{PPT}=\mathrm{ER} \alpha$ agonist 


\section{Abstract}

\section{Background:}

Hair loss/thinning is a common side effect of tamoxifen in estrogen receptor (ER) positive breast cancer therapy. Some nutraceuticals known to promote hair growth are avoided during breast cancer therapy for fear of phytoestrogenic activity. However, not all botanical ingredients have similarities to estrogens, and in fact, no information exists as to the true interaction of these ingredients with tamoxifen. Therefore, this study sought to ascertain the effect of nutraceuticals (+/- estrogen/tamoxifen), on proliferation of breast cancer cells and the relative expression of $E R \alpha / \beta$.

\section{Methods:}

Kelp, Astaxanthin, Saw Palmetto, Tocotrienols, Maca, Horsetail, Resveratrol, Curcumin and Ashwagandha were assessed on proliferation of MCF7, T-47D and BT483 breast cancer cell lines $+/-17 \beta$-estradiol and tamoxifen. Each extract was analysed by high performance liquid chromatography (HPLC) prior to use. Cellular ER $\alpha$ and ER $\beta$ expression was assessed by qRT-PCR and western blot. Changes in the cellular localisation of ERa:ER $\beta$ and their ratio following incubation with the nutraceuticals was confirmed by immunocytochemistry.

\section{Results:}

Estradiol stimulated DNA synthesis in three different breast cancer cell lines: MCF-7, T-47D and BT483, which was inhibited by tamoxifen; this was mirrored by a specific ER $\alpha$ agonist in TD47 and BT483 cells. Nutraceuticals did not interfere with tamoxifen inhibition of estrogen; some even induced further inhibition when combined with tamoxifen. The ERa:ER $\beta$ ratio was higher at mRNA and protein level in all cell lines. However, incubation with nutraceuticals induced a shift to higher ER $\beta$ expression and a localization of ERs around the nuclear periphery.

\section{Conclusions:}

As $\mathrm{ER} \alpha$ is the key driver of estrogen-dependent breast cancer, if nutraceuticals have a higher affinity for ERß they may offer a protective effect, particularly if they synergize and augment 
the actions of tamoxifen. Since ER $\beta$ is the predominant ER in the hair follicle, further studies confirming whether nutraceuticals can shift the ratio towards ER $\beta$ in hair follicle cells would support a role for them in hair growth. Although more research is needed to assess safety and efficacy, this promising data suggests the potential of nutraceuticals as adjuvant therapy for hair loss in breast cancer patients receiving endocrine therapy.

\section{Introduction}

For women the lifetime risk of developing breast cancer is 1 in 8 . Breast cancer is a heterogeneous disease, with several subtypes classified by specific molecular characteristics. Approximately $80 \%$ of all breast cancers express the estrogen receptor (ER) [1]. While there are two different nuclear ERs, namely ERa and ERß, the principal driver of ER-positive breast cancers is ERa. Tumours positive for $\mathrm{ER} \alpha$ comprise two main molecular classifications; luminal A (HER2 negative) with low Ki67 expression, or luminal B, (HER2 positive or negative), with high Ki67 expression. For these subtypes, therapies to block ER $\alpha$ signaling are key to endocrine treatment, hence tamoxifen, an agonist of ER $\alpha$ remains the gold standard treatment [1]. Currently, ER $\beta$ is not a diagnostic marker, or targeted in breast cancer management. However in vitro studies point to an inhibitory role for ER $\beta$ in terms of cell proliferation, migration, and invasiveness [2,3], and induction of autophagy [4,5].

Cell lines established from breast tumours, continue to provide the principal experimental model for cancer research, although significant differences exist between in vitro cell lines and tissue samples [6]. The MCF7 cell line has been propagated for almost 50 years and used extensively in breast cancer research [7]. It is a luminal A breast cancer cell line, isolated from the pleural effusion of a 69-year-old woman with metastatic disease [8] and is ER and progesterone receptor (PR) positive, and HER2 negative. Similarly, BT483 and T47D are also luminal A, ER and PR positive, HER2 negative cell lines [9]. T47D was established from the pleural effusion of a 54-year-old woman with ductal breast carcinoma 
[10], while in contrast, the BT483 line was isolated from a solid, invasive, ductal breast carcinoma of a 23-year-old woman [11]. All three cell lines have been reported to express high levels of ERa protein, while BT483 and T47D also express high levels of prolactin [12]. Endocrine therapy in the form of tamoxifen, which is a selective estrogen receptor modulator (SERM), is prescribed for premenopausal women with ERa-positive breast cancer. Data from the Adjuvant Tamoxifen: Longer Against Shorter (ATLAS) Collaborative Group suggest that 10 years of tamoxifen treatment, as opposed to 5 years, reduces breast cancer mortality by $50 \%$ during the second decade after diagnosis [13]. Therefore, many women are prescribed treatment for up to 10 years. Estrogen modulates many non-reproductive tissues, including the hair follicle [14]. However, in women undergoing anti-estrogen treatment, scalp hair loss/thinning is a reported side effect $[15,16]$. Patterned hair loss comparable to androgenetic alopecia, or male pattern hair loss was reported in a clinical study of 112 women undergoing treatment for breast cancer [17]. A larger study of 19,430 patients with endocrine-related cancers in 35 clinical trials found the highest incidence of alopecia (25.4\%) was in women undergoing tamoxifen treatment in a phase II clinical trial [18]. For many women, endocrine therapy induced hair loss is significant, negatively impacting sociocultural status and quality of life. It can lead to non-compliance of therapy and therefore poses a therapeutic challenge in patients with breast cancer.

Nutritional factors play an important role in hair growth and shedding, with current adjuvant therapies for hair thinning encompassing vitamin supplementation e.g., vitamin D, E, C, folic acid [19], or omega-3 fatty acids, which improve hair density, reducing the percentage of resting hair follicles [20]. There is increasing evidence that a plethora of plant-derived nutraceuticals including resveratrol, saw palmetto, maca, curcumin, tocotrienols, ashwagandha, horsetail, astaxanthin, kelp, annurca apple fruits, safflower and ginseng, can have beneficial effects on hair growth [21-24]. Some e.g., saw palmetto are competitive, nonselective inhibitors of 5a-reductase [25], the key enzyme required in the development of androgenetic alopecia [26]. These polyphenols exhibit anti-inflammatory and antioxidant 
activity, and it may be that their mode of action is a protective one, by reducing oxidative stress in the hair follicle.

While nutraceuticals are available without prescription, physicians are often reluctant to endorse them since potential interactions with endocrine therapy has not been fully elucidated. One prospective study suggests antioxidants taken during chemotherapy, as well as iron and vitamin B12, may increase the risk of recurrence (27), yet there are no randomised studies confirming the outcome of antioxidant supplements in breast cancer patients. However, there are wide-ranging reports that nutraceuticals with beneficial effects on hair growth, including curcumin, tocotrienols, kelp and resveratrol, also exert an anti-proliferative effect on breast cancer cells [23]. Whether this is due to tissue selectivity, e.g., antagonistic SERM in breast cancer cells, or due to a higher affinity for ER $\beta$ remains to be established. The predominant ER in the human hair follicle is $\operatorname{ER} \beta[28,29]$, while in breast cancer cells it is $E R \alpha$, therefore the relative expression and affinity for $E R \alpha$ and $E R \beta$ is of significance. There is some evidence that some plant polyphenol nutraceuticals can downregulate ER $\alpha$ while stabilizing the anti-proliferative $\mathrm{ER} \beta$, resulting in an altered $\mathrm{ER} \alpha \mathrm{ER} \beta$ ratio [30]. The most important aspect of supplements that can improve endocrine therapy induced hair loss for women undergoing breast cancer treatment is that they should not mimic the stimulatory effect of estrogen on breast cancer cell proliferation, or that they compete with the antagonistic action of tamoxifen. Therefore, understanding their mechanism of action is key since many women will be prescribed endocrine-directed therapy in the form of tamoxifen. A recent study has correlated breast cancer cell lines with tumours using 4 different molecular datasets, namely, gene expression, copy number variation, DNA exome sequencing mutation, and protein phosphorylation expression, to identify which commonly used cell lines have the highest similarity to breast tumours [9]. By using the total similarity score from these correlations with molecular profiles, this study identified BT483 and T47D as the breast cancer cell lines with the highest similarity to tumours, while MCF7 ranked $17^{\text {th }}$. 
Therefore, the aim of this study was to compare the effect of nine different nutraceuticals on the MCF7 ER-positive breast cancer cell line, along with two other ER-positive breast cancer cell lines that display the highest similarity to tumours in vivo. Breast cancer cell proliferation was assessed in the presence of each nutraceutical, and compared with the effect of $17 \beta$ estradiol, a specific ER $\alpha$ agonist, and a specific ER $\beta$ agonist. Any ability to interfere with the inhibitory effect of tamoxifen on $17 \beta$-estradiol-stimulated proliferation in each of the cell lines was also evaluated. In addition, changes in the relative expression and cellular localization of ER $\alpha$ and $E R \beta$ in the presence of the combined nutraceuticals was established in each cell line. 


\section{Methods}

\section{Cell Culture}

The cell lines were obtained from European Collection of Authenticated Cell Cultures (MCF7 and T47D) and American Type Culture Collection (BT483). The cell lines were all routinely cultured in complete RPMI containing $2 \%$ FBS (MCF7 and T47D) or 10\% FBS (BT483) in a humidified incubator at $37^{\circ} \mathrm{C}, 5 \% \mathrm{CO}_{2}$.

\section{Quantitative RT-PCR}

Triplicate confluent T75 flasks of each cell line were cultured in serum free RPMI for $48 \mathrm{~h}$ before extraction of RNA using the Aurum ${ }^{\mathrm{TM}}$ Total RNA mini kit. RNA was quantified, normalised, and assessed for purity using a NanoPhotometer and cDNA was synthesised using the iScript ${ }^{\mathrm{TM}}$ Advanced cDNA Synthesis kit. A mastermix was prepared containing SsoAdvanced ${ }^{\mathrm{TM}}$ Universal SYBR ${ }^{\circ}$ Green Supermix, cDNA and primers (PrimePCR SYBR Green Assay, Desalt 200R, human primers, ESR1 \& ESR2 Bio-Rad, UK), before running on a StepOnePlus RT-PCR System (Applied BioSystems, US) under the following conditions: activation $\left(95^{\circ} \mathrm{C}, 2\right.$ mins, 1 cycle), denaturation $\left(95^{\circ} \mathrm{C}, 5\right.$ secs, 40 cycles $)$, annealing lextension $\left(60^{\circ} \mathrm{C}, 30\right.$ secs, 40 cycles $)$, melt curve $\left(65-95^{\circ} \mathrm{C}, 0.5^{\circ} \mathrm{C}\right.$ increments, 5 secs/step, 1 cycle). Results were calculated as gene expression relative to the RPS18 housekeeping gene, calculated via the 2- $\Delta \Delta C T$ (Livak) method in relation to a positive control primer for the gene of interest. A gDNA primer was also amplified to ensure the samples were free from contamination along with a reverse transcription (RT) control and PCR run efficiency control to ensure the $\mathrm{RT}$ and $\mathrm{PCR}$ reactions ran appropriately.

\section{Western Blot}

Triplicate confluent T75 flasks of each cell line were cultured in serum free RPMI culture medium for $48 \mathrm{~h}$ before protein extraction with RIPA Buffer, containing complete ${ }^{\mathrm{TM}}$ Protease Inhibitor Cocktail Tablets (Roche, UK). Cell lysates were briefly sonicated, centrifuged at $14000 \mathrm{rpm}$ for $1 \mathrm{~min}$, the supernatant collected, and protein quantified using the BCA Assay Kit (Pierce, UK). Samples were standardised and diluted in 2x Laemmli Buffer and $\mathrm{dH}_{2} \mathrm{O}$, 


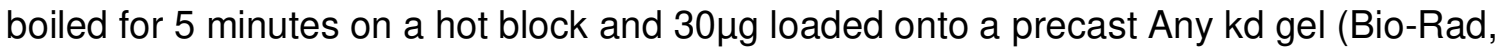
UK) and SDS-PAGE performed at $120 \mathrm{~V}$ for 90 mins. The protein was transferred to LF-PVDF (Bio-Rad, UK) using the Standard SD program on a Transblot Turbo (Bio-Rad, UK). The LFPVDF was blocked in 5\% BSA/PBS for 90mins before the primary antibodies; mouse antiestrogen receptor alpha antibody (Bio-Rad, UK) and estrogen receptor beta polyclonal antibody (Thermo Fisher, UK) were added at 1:1000, diluted in 1\% BSA/PBS, and incubated overnight at $4^{\circ} \mathrm{C}$. Membranes were washed in PBST for 5 mins before washing $3 \mathrm{X}$ in PBS. Alexa Fluor Donkey Anti Mouse 488/Rabbit 647 secondary antibodies (Invitrogen, UK) were diluted 1:1000 in 1\% BSA/PBS. hFAB Rhodamine Anti-GAPDH Primary Antibody (Bio-Rad, UK) was added to the antibody solution at 1:2500 and the membranes incubated in the solution for 90 minutes in the dark, at room temperature on a rocker. Membranes were washed once in PBST then $3 \mathrm{X} t$ in PBS and imaged on a Chemidoc MP Imager on 488/555/647 nm channels. Images were quantified using Image Lab.

\section{Estrogen agonists and antagonists}

Tamoxifen, 17 $\beta$-estradiol, were purchased from Sigma UK, and ERB-041 (ER $\beta$ agonist) and PPT (ER $\alpha$ agonist) from Tocris UK. They were dissolved in DMSO and diluted in serum free RPMI to their working dilutions tamoxifen $(2 \mu \mathrm{M}), 17 \beta$-estradiol (10nM), ERB-041 (100nM) and PPT (100nM).

\section{Extract Origin and Preparation}

Kelp powder extract (Laminaria Digitata) was sourced from Iceland (Thorvin, USA); Astaxanthin powder (Haematococcus pluvialis, 5\% Astaxanthin), was sourced from China; Saw Palmetto powder (Serenoa Repens Fruit), was sourced from the USA; Tocotrienols liquid extract (Elaeis Guineensis Palm Fruit, 20\% tocotrienols), was sourced from Indonesia; Resveratrol powder (Polygonum Cuspidatum, Resveratrol 50\%), was sourced from China; HorseTail powder (Equisetum Arvense), was sourced from China; Ashwaghanda powder (Withania Somnifera) was sourced from India; Maca powder (Lepidium meyenii) was 
sourced from Peru; Curcumin powder (Curcuma Longa Rhizome) and Alternative Curcumin powder (Encapsulated Curcumin, Curcuma Longa Rhizome) were sourced from India. Extracts were dissolved at $100 \mathrm{mg} / \mathrm{ml}$ in DMSO by gentle warming and agitation in a ThermoMixer. If the extract did not go into solution fully it was then sonicated, and then passed through a $0.22 \mu \mathrm{m}$ sterile syringe filter. Extracts were HPLC-MS tested to validate the presence of active ingredients as indicated by manufacturer specification. For combined extract treatments, the top tolerated concentration for each extract, ascertained from the WST-1 cytotoxicity assay (see supplementary Table 1), was combined, and considered $100 \%$ for the purposes of further dilutions.

\section{WST-1 Cytotoxicity Assay}

Cells were seeded into 96 well microplates at a density of $5 \times 10^{3}$ cells/well in and incubated for $24 \mathrm{~h}$ before incubating with each extract in serum free medium at $100,50,10,1$ and 0.1 $\mu \mathrm{g} / \mathrm{ml}$, or $0.1 \%$ DMSO (vehicle control) for 48 and 72 hours. Then the medium was removed, and cells were incubated in $100 \mu \mathrm{l} \mathrm{WST-1} \mathrm{(Abcam,} \mathrm{UK)} \mathrm{diluted} \mathrm{1:10} \mathrm{in} \mathrm{serum-free} \mathrm{medium}$ for 4 hours before measuring absorbance on a Tecan Infinite plate reader at $450 \mathrm{~nm}$.

\section{BrdU Incorporation Proliferation Assay}

Cells were seeded into 96 well microplates at a density of $7 \times 10^{3}$ cells/well and incubated for $24 \mathrm{~h}$ before incubating with extracts diluted in serum free medium, or $0.1 \% \mathrm{DMSO}$ (vehicle control) for $24 \mathrm{~h}$, before $20 \mu \mathrm{l}$ of BrdU reagent (Sigma, UK) was added and they were incubated for a further $24 \mathrm{~h}$. The cells were fixed for 30 mins using the FixDenat solution provided, before incubating for 90mins with the anti BrdU-POD solution at room temperature. The cells were washed $3 \mathrm{X}$ with PBS and once with $\mathrm{dH}_{2} \mathrm{O}$ and incubated with the substrate solution for 30 mins before the absorbance was read on a plate reader (Infinite M200, Tecan, Switzerland) at $370 \mathrm{~nm}$.

\section{Alamar Blue Proliferation Assay}

Cells were seeded into 96 well microplates at a density of $5 \times 10^{3}$ cells/well and incubated for $24 \mathrm{~h}$, before incubating with extracts diluted in serum free medium or $0.1 \%$ DMSO (vehicle control) for $48 \mathrm{~h}$. The medium was removed, and the cells were incubated in $100 \mu \mathrm{l}$ 
Alamar Blue (Invitrogen, UK) diluted 1:10 in serum-free medium for $4 \mathrm{~h}$ in the dark before the fluorescence was read on a Tecan Infinite plate reader at excitation $560 \mathrm{~nm}$, emission $590 \mathrm{~nm}$.

\section{Immunocytochemistry}

Cells were seeded into 8 well chamber slides at a density of $1 \times 10^{4}$ cells/well and cultured for $24 \mathrm{~h}$ and then transferred to serum free medium for $48 \mathrm{~h}$ before fixing in ice-cold methanol for 15 minutes. To assess changes in estrogen receptor expression cells were incubated with the combined extracts diluted in serum free medium for $4 \mathrm{~h}$ and $24 \mathrm{~h}$ before fixing. Cells were air dried, blocked with $10 \%$ donkey serum in phosphate buffered saline (PBS) for $1 \mathrm{~h}$ before incubating with the primary antibody recombinant anti-estrogen receptor alpha antibody and anti- estrogen receptor beta antibody (Abcam, UK), both diluted 1:200 in 1\% donkey serum, overnight at $4^{\circ} \mathrm{C}$. Cells were washed $3 \mathrm{X}$ in PBS before incubating with donkey anti-rabbit alexa fluor 488 and donkey anti-mouse alexa fluor 594 (Invitrogen, UK) secondary antibodies, diluted 1:200 in 1\% donkey serum at room temperature for 90mins. Cells were washed 3X in PBS before mounting with Vectashield Mounting Medium (Vector Labs, UK). The slides were imaged on a Zeiss LSM 510 Confocal Microscope. 10 images were then quantified using Image J. Nuclei were outlined using thresholding and region of interest $(\mathrm{ROI})$ and the staining intensity quantified in total and within nuclei, on a pixels per cell basis 


\section{Results}

\section{All cell lines expressed higher levels of ER $\alpha$ compared to ERB}

All cell lines expressed ER $\alpha$ and ER $\beta$ at the transcript and protein level (Figure 1). However, both mRNA and protein expression of ER $\alpha$ was considerably higher in all three cell lines compared to $E R \beta$, although the ratio differed between the cell lines. The ER $\alpha: E R \beta$ mRNA ratio was highest in the T-47D cells (50:1) and lowest in BT483 (15:1). The difference in protein levels was not as striking, although ER $\alpha$ was still the predominant receptor. In this instance ER $\alpha$ was more highly expressed in the BT483 cell line (11:1) and the lowest in the T-47D cell line (4.7:1).

A

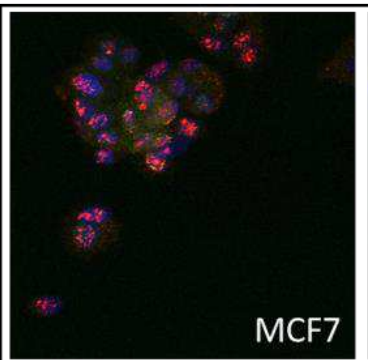

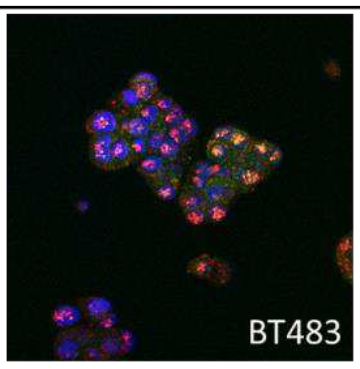

BT483

B

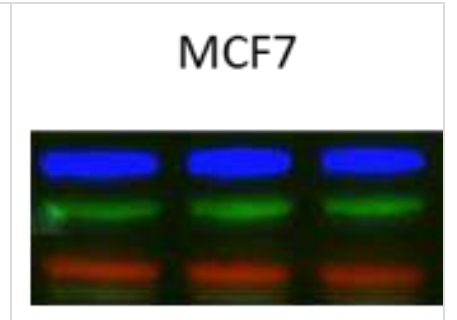

T47D

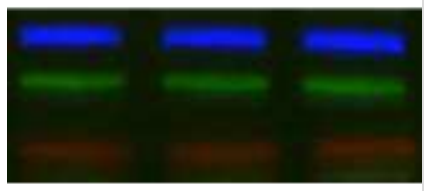

BT483

\begin{tabular}{|c|c|c|}
\hline \multirow{2}{*}{} & \multicolumn{2}{|c|}{ Ratio } \\
\cline { 2 - 3 } & mRNA ER- $\boldsymbol{\alpha}:$ ER- $\boldsymbol{\beta}$ & Protein ER- $\boldsymbol{\alpha}:$ ER- $\boldsymbol{\beta}$ \\
\hline MCF7 & $39.3: 1$ & $6.9: 1$ \\
\hline T47D & $50.1: 1$ & $4.7: 1$ \\
\hline BT483 & $15.0: 1$ & $11.1: 1$ \\
\hline
\end{tabular}

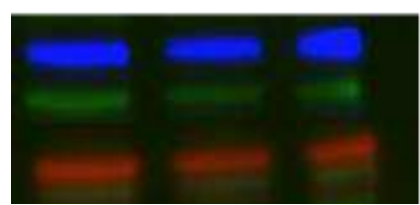

Figure 1.

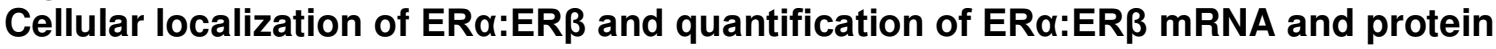
expression in MCF-7, T47D \& BT483 cells

(A) Immunocytochemistry: $E R \alpha=$ green, $E R \beta=$ red, $D A P I=b l u e$, co-localisation = yellow (B) Western blots: $E R \alpha=b l u e, E R \beta=$ reen, GAPDH=red. (C) Quantification of mRNA transcripts by qRT-PCR ( $n=3$ per cell line) and protein expression by quantification of Western blot band density ( $n=3$ per cell line). 


\section{Estrogen stimulation of breast cancer cell proliferation is inhibited by tamoxifen}

Incubation with $10 \mathrm{nM} 17 \beta$-estradiol significantly stimulated cell proliferation in all three cell lines. The most responsive was the BT483 cell line $(101 \%, p<0.0001)$, followed by T-47D $(34 \%, p<0.0001)$ and then MCF-7 (17\%, p<0.0001). Stimulation was inhibited by tamoxifen $(2-5 \mu \mathrm{M})$, and although the degree of inhibition was variable between the three cell lines, proliferation was significantly $(p<0.0001)$ reduced when compared to the effect of $17 \beta$ estradiol (Figure 2). In MCF-7 cells, tamoxifen reduced 17 -estradiol stimulation back down to control levels, while only a partial, yet significant, inhibition, was seen in the BT483 cells. Tamoxifen alone appeared to have an inhibitory effect on the T-47D cells. The ER- $\alpha$ agonist stimulated a similar response to $17 \beta$-estradiol in T47D and BT483 cells, which was similarly negated by tamoxifen. The ER- $\beta$ agonist had no effect on MCF7 or BT483 cells, although induced a slight stimulation in T47D cells. This was negated in the presence of tamoxifen. Interestingly, tamoxifen in the presence of the ER $\beta$ agonist significantly reduced proliferation to below basal levels in the BT483 cell line (Figure 2). Similar responses were also seen when repeated with the Alamar Blue assay (data not shown).
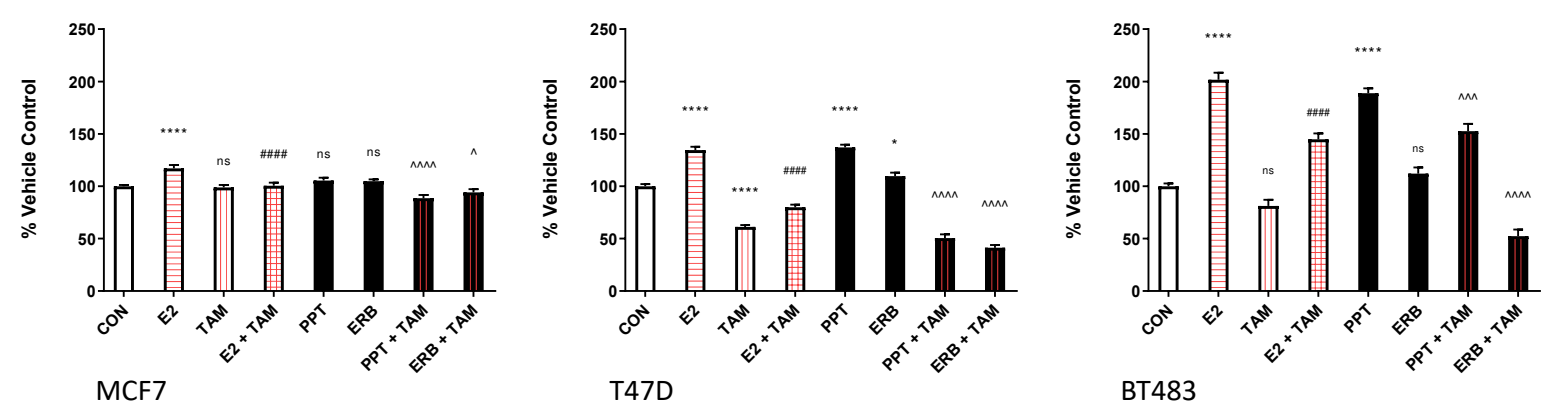

Figure 2.

Cell proliferation is stimulated by $17 \beta$-estradiol and an ER $\alpha$ agonist which is negated by tamoxifen:

Incorporation of BrdU by breast cancer cells MCF-7, T47D and BT483 as a percentage of the vehicle control (+/- SEM of 3 separate assays with 8 experimental replicates). $\mathrm{CON}=$ vehicle control $(0.1 \% \mathrm{DMSO})$; E2 = $17 \beta$-estradiol $(10 \mathrm{nM}) ; \mathrm{TAM}=$ tamoxifen $(2 \mu \mathrm{M})$; PPT (100nM), ERB=ERB-041 (100nM) Cells were incubated for 48 hours. ANOVA (Dunnett's multiple comparison) statistical significance is displayed on the graph above the bars (* denotes significance vs CON. \# denotes significance vs E2.). ${ }^{*} p \leq 0.05,{ }^{* *} p \leq 0.01,{ }^{* * *} p \leq$ $0.001,{ }^{* * *} p \leq 0.0001$, ns non-significant. 


\section{Confirmation of nutraceutical purity and non-toxic concentrations in vitro}

HPLC-MS analysis of the extracts diluted in DMSO confirmed the presence of the active ingredients as indicated by the manufacturer in their specifications (data not shown). A cytotoxicity dose response assay on each of the three different cell lines confirmed the maximum tolerated dose for each individual nutraceutical (supplementary table 1). All were generally well tolerated by all the cell lines with cytotoxicity only observed at the highest concentrations. The bioavailability and pharmacokinetic data for these extracts is limited. However, all appear to have low bioavailability e.g., a 500mg daily supplement of resveratrol results in plasma levels of $70 \mathrm{ng} / \mathrm{ml}$ [31] while circulating levels of tocotrienols are approximately $1 \mu \mathrm{g} / \mathrm{l}$ following oral supplementation with $400 \mathrm{mg}$ [32]. Therefore, since the highest tolerated dose is likely to be supraphysiological we reduced the dose for both resveratrol and tocotrienol to the nanomolar range of $100 \mathrm{ng} / \mathrm{ml}(0.1 \mu \mathrm{g} / \mathrm{ml})$, which was 100 fold lower. To be consistent we used a dose of 100 -fold lower of the maximum tolerated dose for all the other extracts to avoid using supraphysiological concentrations. The concentrations for each extract are indicated in supplementary table 1 and used for all subsequent assays.

\section{Nutraceuticals did not stimulate breast cancer cell proliferation}

The ability of the following nutraceuticals: kelp, astaxanthin, saw palmetto, tocotrienol, maca, horsetail, resveratrol, curcumin, ashwagandha, alternative curcumin, to stimulate proliferation of all three breast cancer cell lines was assessed either on an individual basis, or in combination; extract 1 (all nutraceuticals except alternative curcumin), extract 2 (all nutraceuticals except curcumin). None of the nutraceuticals stimulated cell proliferation, when assessed by the incorporation of BrdU (figure 3), or with the Alamar Blue assay (data not shown). Alternative Curcumin inhibited DNA synthesis in MCF7 cells, while the combined nutraceuticals inhibited it in BT483 cells, 


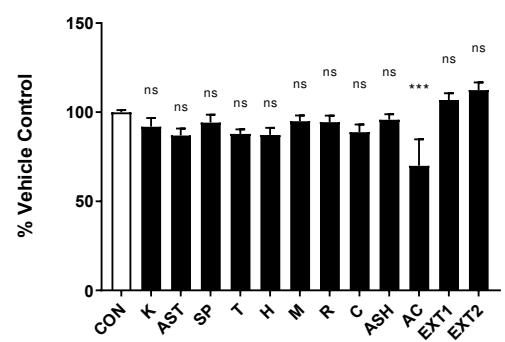

MCF7

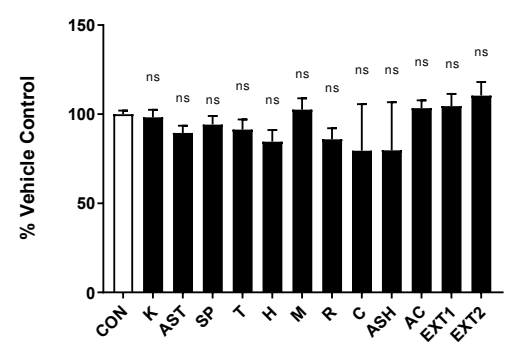

T47D

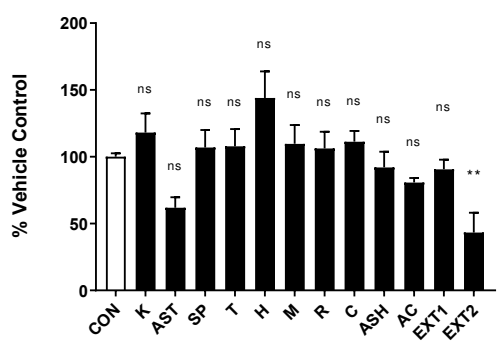

BT483

Figure 3. Nutraceuticals do not stimulate breast cancer cell proliferation: Incorporation of BrdU by breast cells MCF7, T47D, BT483 as a percentage of the vehicle control CON $=$ vehicle control $(0.1 \% \mathrm{DMSO}), \mathrm{K}=\mathrm{Kelp}(0.5 \mu \mathrm{g} / \mathrm{ml})$, Ast=Astaxanthin $(0.1 \mu \mathrm{g} / \mathrm{ml}), S P=S a w$ Palmetto $(0.5 \mu \mathrm{g} / \mathrm{ml}), T=$ Tocotrienols $(0.1 \mu \mathrm{g} / \mathrm{ml}),, M=$ Maca $(1 \mu \mathrm{g} / \mathrm{ml})$, $\mathrm{H}=$ Horsetail $(1 \mu \mathrm{g} / \mathrm{ml}), \mathrm{R}=$ Resveratrol $(0.1 \mu \mathrm{g} / \mathrm{ml}), \mathrm{C}=$ Curcumin $(0.01 \mu \mathrm{g} / \mathrm{ml})$, Ash= Ashwagandha $(1 \mu \mathrm{g} / \mathrm{ml}), A C=$ Alternative Curcumin $(0.1 \mu \mathrm{g} / \mathrm{ml})$ EXT1=All extracts combined except AC (1\%), EXT2=All extracts combined except $C(1 \%)$. Cells were incubated with the nutraceuticals for 48 hours. ANOVA (Dunnett's multiple comparison) statistical significance is displayed on the graph above the bars ( ${ }^{*}$ denotes significance vs vehicle control.) ${ }^{*} p \leq 0.05,{ }^{* *} p \leq$ $0.01,{ }^{* * *} p \leq 0.001$, ns non-significant.

\section{Nutraceuticals did not interfere with the inhibitory effect of tamoxifen on $17 \beta$-estradiol}

\section{stimulated breast cancer cell proliferation}

Nine different nutraceuticals were assessed individually or in combination on their ability to interfere with the tamoxifen inhibition of stimulation by $17 \beta$-estradiol, using two different methods for quantifying cell proliferation. The nutraceutical extracts were incubated in combination with $17 \beta$-estradiol and tamoxifen for $48 \mathrm{~h}$. None interfered with the inhibitory effect of tamoxifen on BrdU incorporation (figure 4). Several further augmented the tamoxifen induced inhibition, although this varied between the different cell lines. In MCF7 cells, kelp, astaxanthin and alternative curcumin acted synergistically with tamoxifen to significantly reduce proliferation compared to tamoxifen alone. Kelp and astaxanthin also had a synergistic effect in T-47D cells, along with saw palmetto, resveratrol, ashwagandha, and curcumin, although alternative-curcumin had no effect. Similar synergy was apparent in 
the BT483 cell line, in the presence of kelp, astaxanthin, saw palmetto and alternative curcumin inducing further inhibition in the presence of tamoxifen (figure 4).

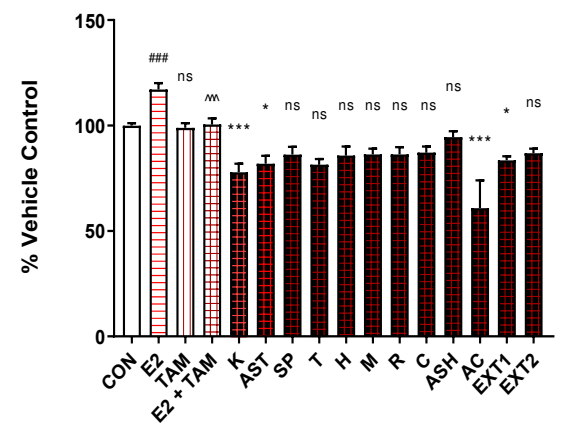

MCF7

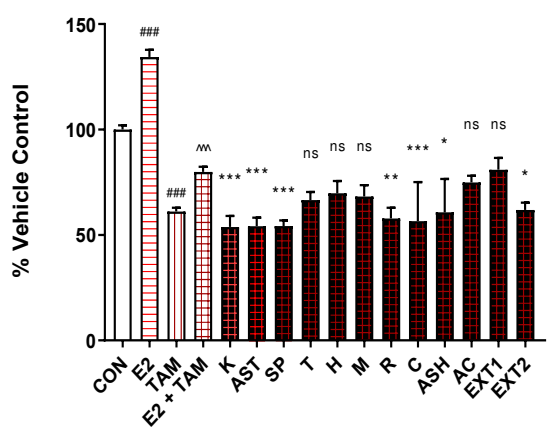

T47D

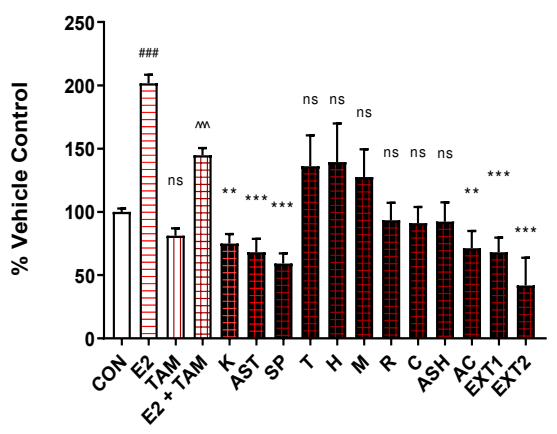

BT483

Figure 4. Nutraceuticals do not interfere with the inhibitory effect of tamoxifen on cell proliferation stimulated by $17 \beta$-estradiol. Incorporation of BrdU by breast cancer cells MCF7, T47D and BT483 as a percentage of the vehicle control (+/- SEM of 3 separate assays): CON = vehicle control (0.1\%DMSO); E2 = 17 $\beta$-estradiol $(10 \mathrm{nM}) ; \mathrm{Tam}=$ tamoxifen $(2 \mu \mathrm{M}) ; \mathrm{K}=\mathrm{Kelp}$ $(0.5 \mu \mathrm{g} / \mathrm{ml})$, Ast=Astaxanthin $(0.1 \mu \mathrm{g} / \mathrm{ml}), \mathrm{SP}=$ Saw Palmetto $(0.5 \mu \mathrm{g} / \mathrm{ml}), T=$ Tocotrienols $(0.1 \mu \mathrm{g} / \mathrm{ml})$, M=Maca $(1 \mu \mathrm{g} / \mathrm{ml}), \mathrm{H}=$ Horsetail $(1 \mu \mathrm{g} / \mathrm{ml}), \mathrm{R}=$ Resveratrol $(0.1 \mu \mathrm{g} / \mathrm{ml}), \mathrm{C}=$ Curcumin $(0.01 \mu \mathrm{g} / \mathrm{ml})$, Ash= Ashwagandha $(1 \mu \mathrm{g} / \mathrm{ml}), A C=$ Alternative Curcumin $(0.1 \mu \mathrm{g} / \mathrm{ml})$ EXT1=All extracts combined except AC (1\%), EXT2=All extracts combined except C (1\%). Cells were incubated with the nutraceuticals for 48 hours in the presence of E2 and tamoxifen. ANOVA (Dunnett's multiple comparison) statistical significance is displayed on the graph above the bars (* denotes significance vs E2 + TAM. \# Denotes significance vs vehicle control. ^ Denotes significance vs E2 treated control). ${ }^{*} p \leq 0.05,{ }^{* *} p \leq 0.01,{ }^{* * *} p \leq 0.001$.

Nutraceuticals induced a shift in the ratio of ERa:ER $\beta$ in breast cancer cells reducing the relative expression of $E R \alpha$ and increasing the relative expression of $E R \beta$

Incubation of breast cancer cells with the combined nutraceuticals, except acumin-curcumin (extract 1), induced a shift in the ratio of ERa:ER $\beta$ protein expression in favour of ER $\beta$

(Table 1). The biggest change was in BT483 cells where a concentration of $1 \%$ stimulated an increase in the ratio of $E R \beta$ to $E R \alpha$ by $159 \%$. In contrast, incubation with the combined nutraceuticals without biocurcumin (extract 2) only increased the ratio of ER $\beta$ in MCF7 and BT483 cells. In the T47D cells the percentage change in the ratio of ERa:ER $\beta$ favoured an increased expression of ER $\alpha$ (Table 1). 
Following incubation for $48 \mathrm{~h}$ with combined extracts of the nutraceuticals (extract 1 and extract 2), a shift in the cellular localisation of both ERs from a general nuclear/cytoplasmic localisation to a specific area around the periphery of the nucleus was induced (figure 5). This was observed in all three cell lines but was most prominent in MCF7 cells.

\begin{tabular}{|c|c|c|c|}
\hline Percentage Reduction in ER $\alpha$ : ER $\beta$ & MCF7 & T47D & BT483 \\
\hline EXT 1 10\% & $75.9 \%$ & $129.1 \%$ & $49.2 \%$ \\
\hline EXT 1 1\% & $66.7 \%$ & $80.2 \%$ & $159.6 \%$ \\
\hline EXT 2 10\% & $82.4 \%$ & $-29.9 \%$ & $54.0 \%$ \\
\hline EXT 2 1\% & $72.8 \%$ & $-49.9 \%$ & $51.2 \%$ \\
\hline
\end{tabular}

Table 1. Shift in ratio of ERa:ER $\beta$ in the presence of combined nutraceuticals Percentage change in ERa:ER $\beta$ compared to the vehicle control when cells were treated for 48 hours with the combined extracts. The total amount of ER $\alpha$ \& ER $\beta$ staining was quantified from randomly selected microscopic fields $(n=5)$ and calculated as total staining present per nuclei. EXT1=All extracts combined except AC, EXT2=All extracts combined except C.

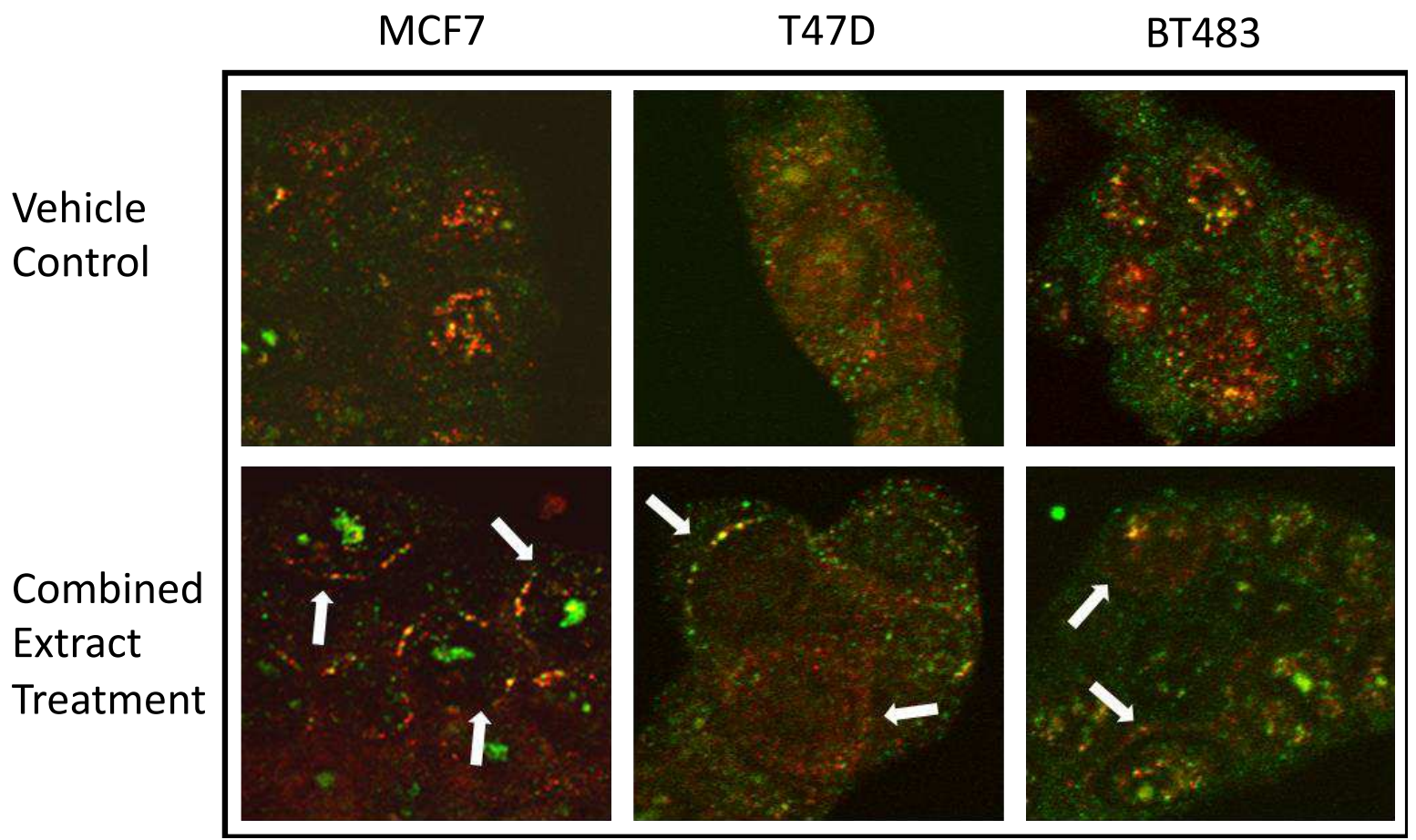

Figure 5. Cellular localization of ER $\alpha: E R \beta$ in presence of combined nutraceuticals. 
Cellular localization of ERa:ER $\beta$ in presence of combined nutraceuticals. Note the distribution of ERs around the nuclear periphery. Left Panel shows MCF7 cells treated with $10 \%$ EXT2, middle panel shows BT483 cells treated with $10 \%$ EXT1, right panel shows T47D cells treated with $1 \%$ EXT1. ERa=green, ER $\beta=$ red, Magnification $=x 630$.

\section{Discussion}

Cell lines established from breast tumours, continue to provide the principal experimental model for cancer research, although significant differences exist between in vitro cell lines and tissue samples [6]. The ER positive MCF7 cell line has been propagated for almost 50 years and used extensively in breast cancer research [7]. A recent study correlating breast cancer cell lines with tumours using molecular datasets, have identified BT483 and T47D as the ER positive cell lines which have the highest similarity to breast tumours [9]. Our study has confirmed that all three cell lines have high ERa and low ER $\beta$ expression, although the ratio varies at both the transcriptome and protein level (figure 1). A previous study also reported much higher expression of ER $\alpha$ compared to ER $\beta$ in MCF7 (93:1) and T47D (23:1) cells by quantifying the proteins via mass spectrometry analysis of 2D-gel spots [33]. This study also compared the proteomic profile of T47D and MCF7 cells, highlighting over 164 proteins were differentially expressed. Proteins with functions in cell proliferation and antiapoptosis were more highly expressed in T47D cells, while proteins involved in the repression of transcription and regulation of apoptosis were more dominant in MCF7 cells. Such differences further substantiate the heterogeneity of breast cancer and underpin the need to confirm responses in more than one cell line.

In terms of stimulation by $17 \beta$-estradiol, the BT483 cell line was the most responsive in our study. Following a $48 \mathrm{~h}$ incubation with $10 \mathrm{nM} 17 \beta$-estradiol DNA synthesis had increased by $101 \%$, (figure 2). In comparison, the stimulation of T47D and MCF7 cells by $17 \beta$-estradiol was more modest at $34 \%$ and $17 \%$ respectively, which is in line with previous studies [34]. 
Under basal conditions BT483 cells grow more slowly [12], so the greater response to $17 \beta-$ estradiol observed in our study may be a result of their higher relative expression of ER $\alpha$ to ER $\beta$ protein. It may also be due having a molecular profile with a much higher similarity to in vivo tumours [9]. Many of the commonly used breast cancer cell lines are derived from pleural effusions, including MCF7 and T47D, whereas BT483 is derived from a solid breast carcinoma [11]

Incubation with PPT, which is a selective ER $\alpha$ modulator with no affinity for ER $\beta$ [35] significantly stimulated proliferation of both T47D and BT483 cells (figure 2), although it did not significantly increase MCF7 proliferation. Again, this may reflect the higher response of T47D and BT483 cells to $17 \beta$-estradiol and their greater similarity to breast tumours compared to MCF7 cells [9]. Incubation with ERB-104, a preferential modulator of ER $\beta$ with 220-fold selectivity for ER $\beta$ over ER $\alpha$ [36] did not stimulate proliferation of MCF7 or BT483 cells (figure 2), although there was a small stimulation in T47D cells. This may be attributed to ER $\alpha: E R \beta$ expression, particularly since the T47D cells had the highest ratio at the transcriptional level and the lowest ratio at the protein level (figure 1). The concentration of ERB-104 used in the current study was 10 -fold higher than that of $17 \beta$-estradiol. A study of botanical estrogens with a higher affinity and selectivity for $\mathrm{ER} \beta$ reported that at high concentrations they were able to stimulate cell proliferation via ERa, highlighting that their concentration and the cellular ERa:ER $\beta$ ratio significantly modulated their subsequent biological effects [37].

Phytoestrogens share some structural similarities to $17 \beta$-estradiol, specifically a phenolic hydroxyl A ring. This structure is paramount for interaction with ER $\alpha$ and $E R \beta$ ligand binding domains, which permits them to simulate the effects of $17 \beta$-estradiol [38]. Since they can modulate agonistic or antagonistic responses, such polyphenolic compounds are deemed to be naturally occurring SERMs [39]. However, several studies have shown that phytoestrogens have a higher affinity for $\operatorname{ER} \beta[40,41]$. To explore the response of human 
breast tumours expressing different ratios of ER $\alpha$ and ER $\beta$, Jiang et al. [37], compared their effects on MCF7 cells containing only ERa, only ER $\beta$, or both ER $\alpha$ and ER $\beta$. They identified that following preferential binding to ER $\beta$, phytoestrogens induced co-activator recruitment and stimulated chromatin binding to enhance expression of ER $\beta$-regulated genes, thereby demonstrating that $E R \alpha: E R \beta$ selectivity and binding affinity of phytoestrogens is augmented at the epigenetic level.

In the current study, none of the nutraceuticals tested, either alone or in combination increased cell proliferation in any of the breast cancer cell lines (figure 3). In MCF7 cells alternative-curcumin inhibited proliferation while the combined nutraceuticals inhibited proliferation in BT483 cells. Of the three breast cancer cell lines examined, BT483 cells have the highest similarity to tumours in vivo [9]. In the present study, BT483 had the highest protein expression of ERa in relation to ER $\beta$ than the other cell lines (figure 1).

However, an important question to address with potential SERMs is whether they can they compete with another SERM, in this case tamoxifen. This is of particular significance for women that may be taking even non-phytoestrogenic nutraceuticals to prevent endocrine therapy induced hair loss [23]. Tamoxifen is a non-steroidal triphenylethylene prescribed to pre-menopausal women for the hormonal treatment of ER positive breast cancer. It interacts with both ERs although its affinity for $\mathrm{ER} \alpha$ is approximately twice that of $\mathrm{ER} \beta$ [42]. However, any competition with binding of tamoxifen to ERs in breast cancer cells would limit its therapeutic capability. Tamoxifen blocked the stimulation of $17 \beta$-estradiol-induced proliferation in all three cells lines demonstrating its effectiveness as an estrogen antagonist (figure 4). In MCF7 and T47D cells, tamoxifen reduced 17 $\beta$-estradiol-induced DNA synthesis back to the basal level, while in BT483 cells, although significantly reduced, it was not fully lowered to basal levels. This is in line with other studies where tamoxifen only partially, but 
significantly inhibited the stimulatory effect of $17 \beta$-estradiol on breast cancer cell lines, including MCF-7, T47D, ZR-75-1 and BT474 [43].

None of the nutraceuticals interfered with the inhibitory effect of tamoxifen on $17 \beta$-estradiolinduced proliferation in any of the cell lines (figure 4). Although variable, several of them further augmented the tamoxifen induced inhibition, reducing proliferation below basal levels indicating a synergistic effect with tamoxifen. Kelp and astaxanthin acted synergistically with tamoxifen to significantly reduce proliferation compared to tamoxifen alone in all three cell lines. Saw palmetto had a synergistic effect in T47D and BT483 cells, while alternative curcumin displayed synergy in MCF7 and BT483 cells, and curcumin in T47D cells. Resveratrol and ashwagandha were also effective in T47D cells (figure 4).

Previously it has been reported that tocotrienols inhibit the proliferation of MCF7 cells, and when combined with tamoxifen reduce proliferation even further [44]. Likewise, while synergy with tamoxifen has not been reported in breast cancer cells, curcumin synergises with tamoxifen in the recovery of $\mathrm{H}_{2} \mathrm{O}_{2}$-induced myocardial apoptosis in ventricular cardiomyocytes of neonatal rats [45]. More recently a study combining novel analogues of resveratrol with tamoxifen demonstrated a synergistic inhibition of the proliferation of breast cancer cell lines, including MCF7 and T47D [46]. Mechanistic studies revealed that in MCF-7 and T47D cells, this synergy was due to down regulation of ERa and the oncogene c-Myc.

Higher expression of $E R \beta$ is associated with improved 5-year disease free survival and overall survival in ERa breast cancer patients [47]. In vitro studies have shown that $17 \beta$ estradiol-induced T47D proliferation was no longer observed when ER $\beta$ expression was increased, demonstrating that the ability of estrogen-like compounds to stimulate cell proliferation are dependent on the cellular ratio of ER $\alpha / E R \beta$ expression, and whether they have a higher affinity for $E R \alpha$ or $E R \beta$ [35]. In the current study incubation with the combined nutraceuticals induced a shift in the protein expression of $E R \alpha / E R \beta$ in favour of $E R \beta$ 
(Table1), suggesting that their effect on reducing cell proliferation may be in part, induced by lower ER $\alpha$ and increased ER $\beta$ activity. An interesting observation was the change in the cellular localisation of ERs following incubation with combined nutraceuticals, to a specific area around the periphery of the nucleus (figure 5), which was observed in all three cell lines. Recently it has been demonstrated that cellular redistribution of mitochondria during the mitochondrial retrograde response (MRR) can be facilitated by contact sites with the nucleus; coined nucleus associated mitochondria (NAM) [48]. It has also been reported that mitochondria express ER $\alpha$ and ER $\beta$ that regulate oxidative stress originating in the mitochondria [49]. Furthermore, in MCF-7 cells, tamoxifen activates mitochondrial ER $\beta$ as an antagonist to inactivate manganese superoxide dismutase which upregulates superoxideinduced apoptosis [50]. Further mechanistic studies to determine the impact of nutraceuticals and their combinations on modifying the $E R \alpha / E R \beta$ ratio, and their potential role in regulating mitochondrial function are required.

Many breast cancer patients are prescribed tamoxifen, but this may induce endocrinetherapy induced hair loss, which for many women is an unacceptable side-effect resulting in non-compliance of treatment. Several nutraceutical formulations have shown clinical efficacy in addressing hair loss and as such may be sought out by patients experiencing thinning on tamoxifen. The most important feature of supplements used in endocrine-therapy induced hair loss is that ingredients should not mimic $17 \beta$-estrogen or compete with the antagonistic action of tamoxifen. The ideal scenario would be an antagonist in breast cancer cells and an agonist in the hair follicle. ER $\beta$ is the predominant ER in the human hair follicle therefore their potential to shift the $E R \alpha / E R \beta$ ratio in favour of $E R \beta$ in hair follicle cells may be of consequence and warrants further investigation. The hair follicle epidermal matrix cells are the second highest proliferative cells in the human body and susceptible to oxidative stress, therefore the antioxidant mechanism action of these nutraceuticals may also be an important contributing factor to their mechanism of action. While further studies are required to assess 
safety and efficacy, this encouraging data supports the safety and potential for use of nutraceuticals as adjuvant therapy for hair loss or thinning in breast cancer patients receiving endocrine therapy.

\section{References}

1. Li, J.; Chen, Z.; Su, K.; Zeng, J. Clinicopathological classification and traditional prognostic indicators of breast cancer. Int J Clin Exp Pathol. 2015, 8, 8500-8505.

2. Hartman, J.; Lindberg, K.; Morani, A.; Inzunza, J.; Strom, A.; Gustafsson, J.A. Estrogen receptor beta inhibits angiogenesis and growth of T47D breast cancer xenografts. Cancer Res. 2006, 66, 11207-13.

3. Song, W.; Tang, L.; Xu, Y.; Sun, Q.; Yang, F.; Guan, X. ERbeta1 inhibits metastasis of androgen receptor-positive triple-negative breast cancer by suppressing ZEB1. Journal of experimental \& clinical cancer research, 2017, 36, 75.

4. Song, P., Li, Y., Dong, Y. et al. Estrogen receptor $\beta$ inhibits breast cancer cells migration and invasion through CLDN6-mediated autophagy. J Exp Clin Cancer Res 2019, 38, 354

5. Ruddy, S.C.; Lau, R.; Cabrita, M.A.; McGregor, C.; McKay, B.C.; Murphy, L.C, et al. Preferential estrogen receptor beta ligands reduce Bcl-2 expression in hormoneresistant breast cancer cells to increase autophagy. Mol Cancer Ther. 2014, 13, 188293.

6. Domcke S, Sinha R, Levine DA, Sander C, Schultz N. Evaluating cell lines as tumour models by comparison of genomic profiles. Nat Commun. 2013;4:2126.

7. Comşa S, Cîmpean AM, Raica M. The Story of MCF-7 Breast Cancer Cell Line: 40 years of Experience in Research. Anticancer Research Jun 2015, 35 (6) 3147-3154

8. Soule HD, Vazguez J, Long A, Albert S, Brennan M: A human cell line from a pleural effusion derived from a breast carcinoma. J Natl Cancer Inst 51: 14091416, 1973.

9. Jiang G, Zhang S, Yazdanparast A, Li M, Pawar AV, Liu Y1, Inavolu SM, Cheng L BMC Genomics 2016, 17(Suppl 7):525 DOI 10.1186/s12864-016-2911-Z

10. Keydar I, Chen L, Karby S, Weiss FR, Delarea J, Radu M, Chaitcik S, Brenner HJ. (1979) Establishment and characterization of a cell line of human breast carcinoma origin, European Journal of Cancer (1965), 15: 659-670,

11. Lasfargues EY, Coutinho WG, Redfield ES. Isolation of two human tumor epithelial cell lines from solid breast carcinomas. J Natl Cancer Inst. 1978 Oct;61(4):967-78. PMID: 212572.

12. Rasmussen LM, Frederiksen KS, Din N, Galsgaard E, Christensen L, Berchtold MW, Panina S (2010). Prolactin and oestrogen synergistically regulate gene expression and proliferation of breast cancer cells. Endocrine-Related Cancer, 17, 809-822. 
13. Davies C, Pan H, Godwin J, et al. Long-term effects of continuing adjuvant tamoxifen to 10 years versus stopping at 5 years after diagnosis of oestrogen receptor-positive breast cancer: ATLAS, a randomised trial [published correction appears in Lancet. 2013 Mar 9;381(9869):804] [published correction appears in Lancet. 2017 May 13;389(10082):1884]. Lancet. 2013;381(9869):805-816. doi:10.1016/S01406736(12)61963-1

14. Thornton M.J. Estrogens and Aging Skin. Dermato-Endocrinology, 2013, 5: 264-270

15. Gallicchio, L.; Calhoun, C.; Helzlsouer, K.J. Aromatase inhibitor therapy and hair loss among breast cancer survivors. Breast Cancer Res Treat 2013, 142, 435-443

16. Park, J.; Kim, J.; Yun, S.K.; Kim, H.U.; Ihm, C.W. Pattern Alopecia during Hormonal Anticancer Therapy in Patients with Breast Cancer. Ann Dermatol. 2014 26, 743-6.

17. Freites-Martinez, A.; Shapiro, J.; Chan, D.; Fornier, M.; Modi, S.; Gajria, D.; Dusza, S.; Goldfarb, S.; Lacouture, M.E. Endocrine Therapy-Induced Alopecia in Patients with Breast Cancer. JAMA Dermatol. 2018 154, 670-675

18. Saggar, V., Wu, S., Dickler, M.N.; Lacouture, M.E. Alopecia with endocrine therapies in patients with cancer. Oncologist. 2013, 18, 1126-34.

19. Karatas, F.; Sahin, S.; Sever, A.R.; Altundag, K. Management of hair loss associated with endocrine therapy in patients with breast cancer: an overview. Springerplus, 2016, 5, 585.

20. Rushton DH Nutritional factors and hair loss. Clin Exp Dermato/ 2002, 27, 396-404.

21. Farris PK, Rogers N, McMichael A, Kogan S. A Novel Multi-Targeting Approach to Treating Hair Loss, Using Standardized Nutraceuticals. J Drugs Dermatol. 2017 Nov 1;16(11):s141-s148. PMID: 29141069.

22. Ablon G, Kogan S. A Six-Month, Randomized, Double-Blind, Placebo-Controlled Study Evaluating the Safety and Efficacy of a Nutraceutical Supplement for Promoting Hair Growth in Women With Self-Perceived Thinning Hair. J Drugs Dermatol. 2018 May 1;17(5):558-565. PMID: 29742189.

23. Dell'Acqua, G.; Richards, A.; Thornton, M.J. (2020) The potential role of nutraceuticals as an adjuvant in breast cancer patients to prevent hair loss induced by endocrine therapy. Nutrients, $12,3537$.

24. Ablon G, Kogan S. A Randomized, Double-Blind, Placebo-Controlled Study of a Nutraceutical Supplement for Promoting Hair Growth in Perimenopausal, Menopausal, and Postmenopausal Women With Thinning Hair. J Drugs Dermatol. 2021 Jan 1;20(1):55-61. doi: 10.36849/JDD.5701. PMID: 33400421.

25. Hosking, A.M, Juhasz., M.; Mesinkovska, N. A. (2019). Complementary and Alternative Treatments for Alopecia: A Comprehensive Review. Skin appendage disorders, 2019, 5, 72-89. 
26. Randall, V.A.; Hibberts NA, Thornton MJ, Hamada K, Merrick AE, Kato S, Jenner TJ, De Oliveira I, Messenger AG. The hair follicle: a paradoxical androgen target organ. Horm Res. 2000, 54, 243-50.

27. Ambrosone CB, Zirpoli GR, Hutson AD et al. (2020) Dietary Supplement Use During Chemotherapy and Survival Outcomes of Patients with Breast Cancer Enrolled in a Cooperative Group Clinical Trial (SWOG S0221). Journal of Clinical Oncology 38: 804-814

28. Thornton, M.J.; Taylor, A.H.; Mulligan, K.; Al-Azzawi, F.; Lyon, C.; O'Driscoll, J.; Messenger, A.G. The distribution of estrogen receptor beta (ERbeta) is distinct to that of ERalpha and the androgen receptor in human skin and the pilosebaceous unit. J Investig Dermatol Symp Proc 2003, 8, 100-103

29. Stevenson, S., Taylor, A.H., Meskiri, A.; Sharpe, D.T.; Thornton, M.J. Differing responses of human follicular and nonfollicular scalp cells in an in vitro wound healing assay: effects of estrogen on vascular endothelial growth factor secretion. Wound Repair Regen. 2008, 16, 243-53.

30. Hahm, E.R.; Lee, J.; Huang, Y.; Singh, S.V. Withaferin a suppresses estrogen receptor- $\alpha$ expression in human breast cancer cells. Mol Carcinog. 2011, 50, 614-24

31. Sergides, C., Chirilă, M., Silvestro, L., Pitta, D., Pittas, A."Bioavailability and safety study of resveratrol $500 \mathrm{mg}$ tablets in healthy male and female volunteers". Experimental and Therapeutic Medicine 11.1 (2016): 164-170.

32. Fu, JY., Che, HL., Tan, D.MY. et al. Bioavailability of tocotrienols: evidence in human studies. Nutr Metab (Lond) 11, 5 (2014). https://doi.org/10.1186/1743-7075-11-5

33. Aka JA, Lin S-X (2012) Comparison of Functional Proteomic Analyses of Human Breast Cancer Cell Lines T47D and MCF7. PLoS ONE 7(2): e31532. doi:10.1371/journal.pone.0031532

34. Wang Y, Xie W, Hou M, et al. Calycosin stimulates the proliferation of endothelial cells, but not breast cancer cells, via a feedback loop involving RP11-65M17.3, BRIP1 and ERa. Aging (Albany NY). 2021;13(8):11026-11042.

doi:10.18632/aging.202641

35. Sotoca AM, van den Berg $H$, Vervoort J, van der Saag P, Ström A, Gustafsson JA, Rietjens I, Murk AJ. Influence of cellular ERalpha/ERbeta ratio on the ERalphaagonist induced proliferation of human T47D breast cancer cells. Toxicol Sci. 2008 Oct;105(2):303-11. doi: 10.1093/toxsci/kfn141. Epub 2008 Jul 21. PMID: 18644836; PMCID: PMC2527638.

36. Cvoro A, Tatomer D, Tee MK, Zogovic T, Harris HA, Leitman DC. Selective Estrogen Receptor- $\beta$ Agonists Repress Transcription of Proinflammatory Genes. The Journal of Immunology January 1, 2008, 180 (1) 630636; DOI: 10.4049/jimmunol.180.1.630

37. Jiang Y., Gong P., Madak-Erdogan Z., Martin T., Jeyakumar M., Carlson K., Khan I., Smillie T.J., Chittiboyina A.G., Rotte S.C.K., et al. Mechanisms enforcing the 
estrogen receptor $\beta$ selectivity of botanical estrogens. FASEB J. 2013;27:4406-4418. doi: $10.1096 / f j .13-234617$.

38. Baker, M.E.; Lathe, R. The promiscuous estrogen receptor: Evolution of physiological estrogens and response to phytochemicals and endocrine disruptors. J Steroid Biochem and $\mathrm{Mol}$ Biol 2018, 184, 29-37

39. Hwang, C.S.; Kwak, H.S.; Lim, H.J., Lee, S.H.; Kang, Y.S.; Choe, T.B.; et al. Isoflavone metabolites and their in vitro dual functions: they can act as an estrogenic agonist or antagonist depending on the estrogen J Steroid Biochem Mol Biol. 2006, $101,246-53$

40. Kuiper GG, Lemmen JG, Carlsson B, Corton JC, Safe SH, van der Saag PT, van der Burg B, Gustafsson JA. Interaction of estrogenic chemicals and phytoestrogens with estrogen receptor beta. Endocrinology. 1998 Oct;139(10):4252-63. doi: 10.1210/endo.139.10.6216. PMID: 9751507.

41. Wang T, Wang Y, Zhuang X, Luan F, Zhao C, Cordeiro MNDS. Interaction of Coumarin Phytoestrogens with $\mathrm{ER}_{\alpha}$ and $\mathrm{ER}_{\beta}$ : A Molecular Dynamics Simulation Study. Molecules. 2020 Mar 5;25(5):1165. doi: 10.3390/molecules25051165. PMID: 32150902; PMCID: PMC7179152.

42. Kasiotis KM, Lambrinidis G, Fokialakis N, Tzanetou EN, Mikros E, Haroutounian SA. Novel Carbonyl Analogs of Tamoxifen: Design, Synthesis, and Biological Evaluation. Front Chem. 2017;5:71. Published 2017 Sep 26. doi:10.3389/fchem.2017.00071

43. Maximov PY, McDaniel RE, Fernandes DJ, et al. Simulation with cells in vitro of tamoxifen treatment in premenopausal breast cancer patients with different CYP2D6 genotypes. Br J Pharmacol. 2014;171(24):5624-5635. doi:10.1111/bph.12864

44. Guthrie N, Gapor A, Chambers AF, Carroll KK. Inhibition of proliferation of estrogen receptor-negative MDA-MB-435 and -positive MCF-7 human breast cancer cells by palm oil tocotrienols and tamoxifen, alone and in combination. J Nutr. 1997 Mar;127(3):544S-548S. doi: 10.1093/jn/127.3.544S. PMID: 9082043.

45. Wan X, Meng J, Dai Y, Zhang Y, Yan S. Visualization of network target crosstalk optimizes drug synergism in myocardial ischemia. PLoS One. 2014;9(2):e88137. Published 2014 Feb 5. doi:10.1371/journal.pone.0088137

46. Ronghe A, Chatterjee A, Bhat NK, Padhye S, Bhat HK. Tamoxifen synergizes with 4(E)-\{(4-hydroxyphenylimino)-methylbenzene, 1,2-diol $\}$ and 4-(E)-\{(p-tolylimino)methylbenzene-1,2-diol\}, novel azaresveratrol analogs, in inhibiting the proliferation of breast cancer cells. Oncotarget. 2016 Aug 9;7(32):51747-51762. doi: 10.18632/oncotarget.10106. PMID: 27351134; PMCID: PMC5239512.

47. Liu J, Guo H, Mao K, Zhang K, Deng H, Liu Q. Impact of estrogen receptor- $\beta$ expression on breast cancer prognosis: a meta-analysis. Breast Cancer Res Treat. 2016 Feb;156(1):149-62. doi: 10.1007/s10549-016-3721-3. Epub 2016 Feb 22. PMID: 26902609. 
48. Desai R, East DA, Hardy L, Faccenda D, Rigon M, Crosby J, et al (2020) Mitochondria Form Contact Sites With The Nucleus To Couple Prosurvival Retrograde Response. Science Advances 18 Dec 2020 : Eabc9955

49. Levin ER, Hammes SR. Nuclear receptors outside the nucleus: extranuclear signalling by steroid receptors. Nat Rev Mol Cell Biol. 2016;17(12):783-797. doi:10.1038/nrm.2016.122

50. Razandi M, Pedram A, Jordan VC, Fuqua S, Levin ER. Tamoxifen regulates cell fate through mitochondrial estrogen receptor beta in breast cancer. Oncogene. $2013 \mathrm{Jul}$ 4;32(27):3274-85. doi: 10.1038/onc.2012.335. Epub 2012 Aug 20. PMID: 22907432; PMCID: PMC3505272.

\section{Declarations}

\section{Ethics approval and consent to participate - Not applicable}

Consent for publication - all authors have approved the manuscript for publication

Availability of data and materials - Data will be made available in the Open Science Framework repository - https://osf.io/

Competing interests - This study was supported by Nutraceutical Wellness, Inc. New York, USA

Funding - This study was supported by Nutraceutical Wellness, Inc. New York, USA

Authors' contributions - RB performed all experimental procedures and analysed data. GD'A contributed to the design of the study and manuscript draft. AR provided feedback on the manuscript. MJT had overall responsibility for the study design and implementation and drafted the manuscript.

Acknowledgements - This study was supported by Nutraceutical Wellness, Inc. New York, USA in collaboration with the Centre for Skin Sciences, University of Bradford, UK 


\section{Supplementary Table 1.}

Table showing suggested maximum experimental concentrations based upon the cytotoxicity observed in the WST-1 assays. 2 log-fold dilutions from the maximum tolerated concentration were also tested in subsequent experiments. Green shading denotes selected maximum concentrations.

\begin{tabular}{|l|c|c|c|c|}
\hline & MCF7 & T47D & BT483 & \\
\hline \multicolumn{1}{|c|}{ Extract } & \multicolumn{3}{|c|}{$\begin{array}{c}\text { Max tolerated dose } \\
(\boldsymbol{\mu g} / \mathbf{m l})\end{array}$} & $\begin{array}{c}\text { Experimental Dose } \\
(\boldsymbol{\mu g} / \mathbf{m l})\end{array}$ \\
\hline Kelp & 100 & 50 & 100 & $\mathbf{0 . 5}$ \\
\hline Astaxanthin & 50 & 10 & 50 & $\mathbf{0 . 1}$ \\
\hline Saw Palmetto & 50 & 50 & 100 & $\mathbf{0 . 5}$ \\
\hline Tocotrienols & 10 & 10 & 50 & $\mathbf{0 . 1}$ \\
\hline Horsetail & 100 & 100 & 100 & $\mathbf{1 . 0}$ \\
\hline Maca & 100 & 100 & 100 & $\mathbf{1 . 0}$ \\
\hline Resveratrol & 10 & 10 & 100 & $\mathbf{0 . 1}$ \\
\hline Curcumin & 1 & 10 & 10 & $\mathbf{0 . 0 1}$ \\
\hline Ashwagandha & 100 & 100 & 100 & $\mathbf{1 . 0}$ \\
\hline Alternative Curcumin & 10 & 10 & 50 & $\mathbf{0 . 1 0}$ \\
\hline
\end{tabular}

